\title{
Halide Edip'te Eğitim Fikri ve Onun Talim ve Terbiye İsimli Eseri
}

\author{
DOI: 10.26466/opus.595764
}

\author{
Hamza Altın * \\ * Doç. Dr, Bingöl Üniversitesi, Fen-Edebiyat Fakültesi, Bingöl / Türkiye \\ E-Posta: hamzaaltin23@gmail.com \\ ORCID: 0000-0002-0747-6904 \\ $\ddot{O} z$
}

II. Meşrutiyet devrinin (1908-1914) edebiyat ve fikir alanında öne çıkmış bir kadın yazarı olan Halide Edip, Meşrutiyetin başlangıcında özellikle kızlara ait okulların açılması konusunda çaba gösterdi. Kadın hareketleri bakımından en önemli eseri sayılan ütopik romanı "Yeni Turan"da kadınlar İstanbul dışında Erzurum'da okullar açmışlardı. Halide Edip, II. Meşrutiyetin ilanından sonra Tanin, Musavver, Türk Yurdu vb. gazete ve dergilerde yazdı̆̆ı makalelerin önemli kısmını talim-terbiye meselesi teşkil etmekteydi. O, kadınların eğitimine büyük önem vermekteydi. Çünkü kadınlar, eğitilmeden kendilerine verilen hakların hiç birisinden faydalanması mümkün değildir. $O$, kadın yetişecek neslin ilk öğretmeni olarak düşünmekteydi. Meşrutiyetten sonra bu idare için yeni insan tipi gerekmektedir. Yeni insan tipi için ise; 1. Yeni eğitim ve öğretim 2. Bunu gerçekleştirecek öğretmen ve anneler gereklidir. Oysa Türk kadını buna hazır değildi. Halide Edip, Talim ve Terbiye isimli eserini İstanbul Kız Öğretmen Okulu'nda (Dârülmuallimât) öğretmenlik yaptığı sırada kaleme aldı. Bu eseri, Amerikalı eğitimci Horn'un Ilm-i Talimin Psikolojik Esaslar isimli eserinin Türkçe tercümesine kendi fikirlerini ekleyerek oluşturdu. Halide Edip, Talim ve Terbiye'de genel eğitim düşüncelerinin yanında öğretmenlere çeşitli tavsiyelerde de bulundu. Bu öğ̈̈tlerden biri de ders kitapları konusundaydı. Ona göre kitap bir rehberdir ve öyle olmalıdır. Katiyen ezberlenecek "Bir emir" olmamalıdır. Bir öğretmen okutulan ders kitabında bazı konular katılmıyorsa bunu sinıfta dile getirme cesaretine sahip olmalıdır. "Hakiki bir muallim kitap muallimi değil, hakikat muallimidir." Kitap öğretmenin yalnızca bir aracı olmalıdır.

Anahtar Kelimeler: Halide Edip, Eğitim, Talim, Öğretmen, II. Meşrutiyet 


\title{
The Idea of Education in Halide Edip's Works and Her Work "Teaching and Education"
}

\begin{abstract}
Halide Edip, who was a prominent female author in literature and philosophy during 2 nd Constitutional Monarchy Period, worked for the establishment of girls' schools in early constitutional monarchy. Her utopian novel "New Turan", which is considered her most important work on women's movement, women established schools in Erzurum in addition to Istanbul. Halide Edip, after the declaration of the 2nd Constitutional Monarchy, wrote significant number of educational articles in newspapers and journals such as Tanin, Musavver, Turkish Land, etc. Education of women was very important for her. Because, it is not possible for women to benefit from any women's rights without education. She considered women as the first teacher of future generations. After the declaration of the 2 nd Constitutional Monarchy, a new type of people was required for the new administration. For the new type of people; 1. New education and instruction 2. Teachers and mothers who would conduct the new education were required. However, the Turkish women were not ready for this change. Halide Edip authored her book titled "Education (Talim ve Terbiye)" during the years when she worked as a teacher in Istanbul Girls' Teacher Training School (Darülmuallimat). The manuscript was written by adding her own ideas to the Turkish translation of the book "The Psychological Principles of Educational Science" by the English educator Horn. In addition to her general ideas on education, Halide Edip provided certain recommendations for teachers in her book "Education". One of these recommendations was about the textbooks. According to her, the book is and should be a guide. It should never be an "order" that should be memorized. When a teacher does not agree even with certain issues mentioned in a textbook, she or he should have the courage to express this in the classroom during instruction. "A true teacher is not a teacher of the books, but a teacher of the truth." The textbooks should be only one of the tools that the teacher utilizes.
\end{abstract}

Keywords: Halide Edip, Education, Exercise, Teacher, Constitutialion Monarchy 


\section{Giriş}

1884 yılında İstanbul'da dünyaya gelen Halide Edip'in, babası Selanikli Mehmet Edip Bey, annesi Bedrifam Hanım'dır. Küçük yaşta annesinin ölümü üzerine ona ilk eğitimini verecek olan anneannesi baktı (Adıvar, 2005, s.1-13, 53). Babasının isteğiyle Üsküdar Amerikan Kız Koleji'nde eğitim gördü (Adıvar, 2005, s.124-126). Halide Edip'in Amerikan kolejinde eğitim görmesinin kendisinin eğitimci kişiliğinin oluşmasında etkisi olsa gerektir. Zira o dönemde İstanbul başta olmak üzere çeşitli vilayetlerde açlan (Beyrut, Tarsus, Amasya, Erzurum, Kayseri, İzmir vb.) söz konusu kolejler, kız çocuklarının eğitimi, yabancı lisan öğretimi ve daha önemlisi çağdaş bir eğitim metoduna geçişte örnek olmaktayd1 (Koçak, 2017, s.71). Okul açıldıktan yaklaşık otuz yıl sonra 1901 yılında mezun olan Halide Edip adı geçen okulun ilk Türk mezunudur (Acun, 2015, s. 420). Bundan başka devrin tanınmış hocalarından Salih Zeki'den Matematik, Rıza Tevfik'ten Felsefe ve Türk Edebiyatı, Şükrü Efendi'den Arapça dersleri aldı (Adıvar, 2005, s.119, 121, 131).

Halide Edip, ilk evliliğini genç yaşta Salih Zeki ile yaptı. Dokuz yıl süren bu evlilikten iki oğlu oldu (Adıvar, 2005, s.133,137). Otuz bir Mart Vakası sırasında bir takım tehditler aldığı için Mısır'a kaçtı. Ülkede istikrar sağlandıktan sonra İstanbul'a geri döndü ve Dârülmuallimât'ta pedagoji öğretmenliğine başladı (Enginün, 1988, s.376). Bu dönemden itibaren eğitim alanında çalışmalarını yoğunlaştırdı. Özellikle kızların eğitimi ile ilgili çalışmalarda bulundu. Yine bu dönemde, hatıratında halkı tanımak için yararından bahsettiği, Evkaf Kız Mektepleri Müfettişliği yaptı (Adivar, 2005, s.201).

Birinci Dünya Savaşı Sırasında Cemal Paşa'nın daveti üzerine eğitim ile ilgili çalışmalarda bulunmak üzere Suriye ve Lübnan'a gitti (Adıvar, 2005, s. 201,220-254). Suriye'de bulunduğu sirada Dr. Adnan Adıvar ile ikinci evliliğini yaptı (Enginün, 1988, s.376).

Ülke işgaline karşı İstanbul'da 19 Mart 1919 tarihinde İnas Dârülfununu öğrencileri ve Asri Kadınlar Cemiyeti üyeleri tarafından düzenlenen mitingde en hararetli konuşmalardan birini Halide Edip yapmıştı (Şenel, 2013, s.13). Yine İzmir'in işgali ile ilgili olarak 23 Mayıs 1919 günü İstanbul'da Sultanahmet Meydanı'nda düzenlenen protesto miting- 
lerinin en ses getiren hatibi Halide Edip olmuş, çoğunluğunu her kesimden kadınların oluşturduğu iki yüz bin kişilik bir kalabalığa seslenerek onlara bağımsızlık yemini ettirmişti (Şahin, 2013, s.61-62).

Halide Edip, Kurtuluş Savaşı'na eşi Adnan Adıvar ile birlikte aktif olarak katıldı. Cephe gerisinde kurulan Kızılay Hastanelerinde çalışmak, Yunanlıların Türklere yaptıkları eziyetleri tespit edip yayınlayan Tetkik-i Mezalim Komisyonunda bulunmak, Hâkimiyet-i Milliye gazetesinde çalışmak ve bunları yaparken İstanbul basınına Kurtuluş Savaşı'nın lehine yazılar göndermek, cepheye cephane taşıyan kadınlara maneviyat hizmeti görmek, Halide Edip'in bu dönemdeki hizmetleri oldu (Kabakl1, 1997, s.679). Mustafa Kemal, İstiklal Harbi'nde, karargâhında vazife yapan Halide Edip'e onbaşılık rütbesi vermişti (Aydın, 2015, s. 91). Yine bu dönemde Kurtuluş savaşı ile ilgili doğru bilgileri dünyaya iletmek amacıyla kurulması gündeme gelen ajansın isminin "Anadolu" olması Yunus Nadi'den öğrendiğimize göre Halide Edip'e aittir. Dolayısı ile kendisi Anadolu Ajansının isim annesidir (Gönenç, 2014, s.83).

Halide Edip' in Anadolu hareketi içerisinde yer alması İstanbul'da hoş karşılanmadı ve mütareke basını tarafından şiddetle eleştirildi. Örneğin Ali Kemal başyazar olduğu Peyam-ı Sabah gazetesinden Halide Edip'e açık mektup yazmaktaydı. Mektubunda Mustafa Kemal'e de hakaret eden Ali Kemal, Halide Edip'i suçlamaktaydı (Ali Kemal, 1339, s.1).

Halide Edip, Cumhuriyetin ilanından sonra da boş durmadı ve kocası ile birlikte Terakkiperver Cumhuriyet Fıkrasının safında yer aldı. Ancak adı geçen partinin kapatılması üzerine Dr. Adnan Adıvar ile birlikte yurt dışına çıktı (1925) ve Atatürk'ün ölümüne kadar da yurda dönmedi. Yurt dışında İngiltere ve Fransa'da yaşadı. Amerika ve Hindistan'da konferanslar verdi (Bilkan, 2005, s.119; Dolu, 1968, s.64-66). Yurda döndükten sonra ise Profesör sıfatıyla İstanbul Üniversitesi Edebiyat Fakültesi'nde İngiliz Dili ve Edebiyatı kürsüsünü kurdu ve 1950 yılına kadar bu görevini sürdürdü (Kaplan, 1992, s.116). Bu tarihte siyasete atılarak Demokrat Parti Listesinden İzmir Milletvekili seçildi.

Halide Edip'in devrinde Osmanlı kadınlarının okulda eğitim almadıkları, nadiren siyasi bir faaliyet içerisinde yer aldıkları dikkate alındığında onun hikâyesinin takdire şayan olduğu ortaya çıkar (Kazan, 1995, s.9). 
9 Ocak 1964 yılında İstanbul'da hayatını kaybeden Halide Edip, burada Merkez Efendi Mezarlığına defin ediliştir (Enginün, 1988, s.376).

\section{Halide Edip ve Eğitim}

\section{Halide Edip'in Eğitim Düşüncesi}

Halide Edip'in, öğretmenliğe başladığı ve eğitim düşüncesini ilk kaleme aldığı yıllar II. Meşrutiyet devrine rastlamaktadır. Bazı yazarların haklı olarak "Bocalama Yılları" dediği bu yıllarda ülkede istikrar yoktu. Bu durum eğitim için de söz konusu idi. Mütareke dönemine kadar toplam on sekiz defa Maarif Nazırı değişmişti. Bu nazırların on altısı bir yıldan az bir süre görev yapmışlardı. Bu nazırlardan icraatı bakımından en göze çarpanı Emrullah Efendi'dir (Altın, 2010, s.151-165).

Halide Edip romanlarıyla ön plana çıkan bir yazardı. Fakat özellikle kadınların eğitimi ile ilgili yazdıkları, romanlarında dile getirdiği eğitime ait düşünceler, ifa ettiği öğretmenlik ve müfettişlik mesleği ve yayınladığ 1 Talim ve Terbiye isimli eser dikkate değerdir. Bütün bu özellikleri dolayısıyla onu aynı zamanda bir eğitimci olarak da değerlendirmek yerinde olacaktır.

Halide Edip'in II. Meşrutiyetin ilanından sonra Tanin, Musavver, Türk Yurdu vb. gazete ve dergilerde yazdığı makalelerin önemli kısmını terbiye ve eğitim meselesi teşkil etmekteydi. Devletin yıkılışına kadar Osmanlının eğitim alanındaki sıkıntılarına dikkat çekmeye çalıştı. Örneğin 1918 yılında yayınlanan bir makalesinde birçok açıdan Anadolu'nun durumunun parlak olmadığını dile getirmekteydi. Bu konulardan biri de eğitimdi. Eğitimin yetersiz olduğunu İstanbul' da bile yeterli sayıda öğretmenin bulunmadığını vurgulamaktaydı (Halide Edip, 1918, s.1).

Halide Edip, her şeyden önce bir öğretmen olarak eğitimin içinde bulunmuştur. II. Meşrutiyet devrinde Trablusgarp ve özellikle Balkan savaşları gibi ülkeyi felakete sürükleyen savaşlar neticesinde memleket gerçekten zor durumdaydı. İşte bu şartlarda Maarif Nazırlığından, eğitimle ilgilenmesi nedeniyle Halide Edip'e öğretmenlik teklif edildi. Aslında Halide Edip daha evvel öğretmenlik yapmayı düşünmemekteydi. Fakat vatanın içinde bulunduğu şartlardan dolayı bu teklifi kabul etti. Çünkü onun fikrince bu çetin zamanlarda eğitimli her Türk gencinin vazifesi, lüzum olan bölgelerde öğretmenlik yapmaktı. Halide Edip, ünlü 
eğitimci Nakiye Hanım'la birlikte işe başladı. Nakiye Hanım Dârülmuallimât'a müdür, Halide Edip ise usul-i tedris muallimi sıfatıyla vazifeye başladı. Halide Edip, bu okulda ve idadide beş yıl süreyle muallime olarak vazife icra etti (Erdal, 2005, s.48). Fakat dönemin Maarif Nazırı ile ters düşünce öğretmenlik mesleğinden istifa etti. 1913 yılında aşağıda ilk paragrafı verilen istifa dilekçesini sundu. Dilekçede okul müdürü ile anlaşmazlık dile getirilse de asıl sorun Maarif Nazırı ile yaşanmıştı.

"Dârülmuallimât tarih dersimden evvela mektepte tuttukları tarz-ı idâreye iştirak edemeyeceğimden, saniyen mektep idâresinin ikinci gittiğim gün beni maruz ettiği hakaretten dolayı isti'fâmı zât-ı nezâretpenâhilerine takdim ediyorum. Kurûn-ı vustâ saraylarında olduğu gibi her girenin yakasina atılan bir harem ağasının nezaketsiz muamelesi gözünün önünde cereyan ettiğ i halde müdahale edip ağayı tedip etmedikten başka şahsıma da hürmetsizlik eden mektep müdürü Refik Bey Efendi'nin, hareket-i vak'asını, maârifin bir muallimi sıfatıyla şiddetle protesto eder ve maârif nezâret-i celilesinin müdür bey efendiye muallimlerin birer hizmetkâr olmadıkları kanaatinin dâr-ül-muallimât gibi bir müesseseyi idâre eden zihniyetlerde tayin etmesi lazım geleceğini anlatmasın temenni ederim." Talat Bey ve Ziya Gökalp'in araya girmesi istifayı erteledi ama sonuç değişmedi. (Taşer, 2012, s.152-153).

Halide Edip, İttihatçıların ünlü şeyhülislamı Mustafa Hayri Efendi'nin Evkaf kız mekteplerini modernleştirme çabaları sırasında Evkaf kız mekteplerinin umumi müfettişliği görevini kabul etti (Adıvar, 2000, s.200). Yazar Mor Salkımlı Ev isimli hatıratında konudan bahsederken şunları söylemekteydi:

"Hayri Efendi'nin Evkaf mektepleri o günlerde fikir ve ilim sahasinda cidden modern ve ileri bir yol tutmuşlardı. Müslüman cemaatinin elinde böyle bir teşkilatın kalmış olması bizim için çok hayırlı olur, hiç olmazsa Müslüman olmayan cemaatlerden geri kalmazdr." Halide Edip, müfettişlik mesleğini büyük bir özveriyle yaptı. Sadece adı geçen mektepleri değil öğrencilerin ailelerini de ziyaret etti. Yine hatıratında bu mevzudan bahsetmiştir:

"Evkaf kız mekteplerinin umumi müfettişliği bana, halkı ve muhtelif semtleri içinden görmek için bir vesile oldu. Her hafta İstanbul'un hiç bilmediğim arka sokaklarma, fakir muhitlere giderdim ve buralarda sadece Evkaf mekteplerini değil, çocuk ailelerini de tanımaya muvaffak oldum. Kasımpaşa ve Sineklibakkal, bilhassa Sineklibakkal en fazla dolaştığım yerlerdi" (Adıvar, 2000, s.201). 
Halide Edip, başka bir hocalık deneyimini de İstanbul Darülfünunda gerçekleştirmiştir. 1918-1919 yıllarında İstanbul Darülfünunda Batı Edebiyatı dersleri okutmuştur. $O$, öğretmenlik mesleği vazifesini yurtdışında da sürdürmüştür. 1931 tarihinde Colombia Üniversitesi Bernard College'den davet almış ve burada Tarih bölümünde öğrencilerin yoğun ilgisini çeken dersler vermiştir (Erdal, 2005, s.14-15).

Halide Edip, Darülfünunda kızlar ile erkeklerin birlikte ders görmeleri ile ilgili tartışmaya katılarak karma eğitimi onaylamaktaydı. Ona göre nasıl kadın ve erkek mağazada birlikte satıcılık yapıyorsa aynı şekilde "Darülfunun dershanesinde de erkek kadın arkadaşıyla yan yana oturmak hakkın itiraz kabul etmez derecede kazanmıştı"' (Halide Edip, 1335, s.89).

Halide Edip, Isabel Fry'ın davetlisi olarak İngiltere'ye gitti. Burada başta eğitim olmak üzere birçok konuda gözlemlerde bulundu. İngiltere' de aydın bir çevre ile iletişimi oldu bu şekilde fikirlerini olgunlaştırdı. Halide Edip'in eserlerinde ve idealize ettiği eğitim sisteminde İngiliz etkisinin olmasında, okuduğu okulların yanı sıra bu gezinin de etkisi olduğunu düşünebiliriz (Sönmez, 2014, s.218).

Yurt dişından döndükten sonra 1940 yılında İstanbul Üniversitesi Edebiyat Fakültesi'nde İngiliz Edebiyatı profesörü olarak göreve başlamış ve 1940-1950 yılları arasında on yıl süreyle ders vermiştir (Erdal, 2008, s. 410, 411). Halide Edip, on yıl süreyle icra ettiği üniversite hocalığı süresince, yazdığı makalelerle üniversite çalışanlarının karşılaştığı problemleri ve üniversitenin islah ve modern bir kurum olması için neler yapılması gerektiği konularına değinmiştir (Erdal, 2005, s.16).

Halide Edip, İzmir milletvekili olduğu dönemde de eğitim konusuyla ilgilenmeye devam etti. Millî Eğitim ve Anayasa komisyonlarında vazife aldı. Mecliste yaptığ eğitimin önemi üzerinde durdu. (Müezzinoğlu, 2017, s.331-332).

Halide Edip, Osmanlının yaşadığı problemlerin kaynağında Türklük şuurunun dumura uğramasını görmekteydi ve bunda eğitimin daha doğrusu eğitimsizliğin etkisi vardı. Bu görüşünü şu cümleler ile ifade etmekteydi:

"Kurtuluş için, dindar, haysiyetli, çalışkan olmakla beraber, başka bir şey daha lâzımdır. O da her şeyden evvel şiddetle Türk olmaktır. Bir millet, millet halinde kalmak, öteki milletlere karşı mevcudiyetini muhafaza etmek için mutlak milliyetperver olmalıdır. Bu milliyetperverliktir ki, Türk milletini evvela büyük bir 
millet yapmış, bu hissin bizden gitmesi de tarihi şerefimizi eksiltmiş, bizi kuvvetten düşürmüştür. Yine düşmanlarımızı da bu milliyetperverliktir ki, onları yarım asır evvel hâlâ bugün sütçülerimiz, bilmem daha nelerimiz diye tahkir ettiğimiz Bulgarlar bir millet, Avrupa'nın hatırı sayacağ̆ bir millet haline getirmiş, Fatihlerin, Selimlerin hüküm sürdüğ̈̈ Türk ülkelerini onlara çiğnetmiştir. Milleti ile iftihar etmeyi bilmeyen, milletini sevmeyi bilmeyen, milliyet hisleri ile uyanması en geride kalan bir millet maatteessüf bizler, Osmanlı Türkleriyiz." (Kurnaz, 1991, s.15-23).

Osmanlıya sıkıntı yaşatan şuur eksikliği ancak eğitim ile izale edilebilirdi. Halide Edip'in eğitim düşüncesinde halkı eğitmek önemli bir yer tutar. Bunu Türk milli kimliğini oluşturmak için yapmak gerekmektedir. Onun fikrine göre oluşturulacak milli kimliğin temel taşları milliyetçilik, batılılaşma ve modernize olmuş bir din anlayışı idi. Zira yeni insan tipinin karışındaki en büyük engel bağnaz din adamıydı (Gözütok, 2010, s. 411412).

Halide Edip, eğitimde özgürlükten ve çeşitlilikten yanaydı. Eğitimin maarif nazırlığının tekelinde olması fikrine karşı soğuktu. Belediyeler, vakıflar vb. kuruluşlar da pekâlâ eğitim veren kuruluşlar oluşturabilir lerdi (Halide Edip, 1924, s.4).

\section{Halide Edip'in Kıların Eğitimine Ait Düşüncesi}

Halide Edip, eğitim ile ilgili düşüncelerini yazmaya başladı̆̆ı II. Meşrutiyet devrinde birçok eğitim akımı bulunmaktaydı (seçkinler eğitimi akımı, iş okulu akımı, kitle eğitimi akımı vb.) Bu akımlardan biri de kadın eğitimi akımıydı ve bu akımın yegâne temsilcisi Halide Edip idi (Ergün, 1996, s.4).

Halide Edip'in, dünya görüşüne göre kadın ve erkek toplumda iç içe ve yan yanadır. Dolayısıyla eğitim anlayışı da bu çerçevede şekillenmiştir. Onun fikrine göre bunu sağlamak için özellikle kadını eğitmekle işe başlanmalıdır. Erkek ve kadın sosyal hayatta birlikte rol almalıdır. Toplumsal yapının kaliteli olması kadının eğitiminden geçmektedir. Bu manada yazar karma eğitimden yanadır. Ayrıca kadınlarda erkeklere nispeten eksik olan milli şuur eğitim yoluyla onlara kazandırılmalıdır (Bilge, 2012, s.43-61). 
II. Meşrutiyet devrinde Türkçü akımına mensup aydınlar kadın erkek eşitliğinin cehaletten dolayı bozulduğunu, bu durumun tekrar ihya edilmesi için hukukî ve içtimaî sslahatların yapılması gerektiğini ileri sürmüşlerdir. Bu düşünürlerden biri olan Halide Edip, ülkenin gelişmesi için kadının statüsün yükseltilmesi bunun ise eğitimle kabil olabileceğini savunmuştur (Özkiraz, 2011, s.8). Söz konusu devrin edebiyat ve fikir alanında öne çıkmış bir kadın yazarı olan Halide Edip, Meşrutiyetin başlangıcında özellikle kızlara ait okulların ve bazı kurumların açılması konusunda çaba gösterdi (Taşkıran, 1973, s.58).

Mehasin isimli mecmuada yer alan bir makalesinde "kadınlar asırlardan beri bizde ezilmiş, istihfaf edilmiş" bir unsurdu diyen Halide Edip, bunun böyle gitmemesi için içtimai hayatta yeniliklerin yapılması gerektiğini belirtiyordu bu yenilikler ise toplumun eğitimi ile mümkün olacaktı (Halide Salih, 1324a, s.418-421). Bu düşünceyle kadınların eğitimi ve toplum hayatına katılabilmesi için Teali-i Nisvan Cemiyeti'ni kurdu. Bu cemiyet, Osmanlının yaşadığı büyük felaketlerden biri olan Balkan Savaşı sırasında kadınların çeşitli konularda eğitilmesi örneğin hasta bakıcı olarak çalışma hayatında yer alması için gayret sarf etmiştir. Cemiyet, savaş esnasında dahi kadının eğitimi konusunu ihmal etmek istememiş, cemiyete üye hanımlar "kadınlarımızda seviye-i irfanımızın itilası" için mücadele etmiştir (İnce, 2015, s.13).

Halide Edip'in eğitime dair bir başka faaliyeti de Suriye'de gerçekleşmiştir. 1916 yılında Türk Ocağında verdiği Ermeni konferansından sonra aldığı olumsuz tepkiler üzerine Cemal Paşa'nın davetiyle, bir grup aydınla birlikte Suriye'ye gitmiştir (Altay, 2010, s.77). Bölgede okullar ve darüleytamlar (yetimhane) ile ilgili olarak mesai harcayan ve yeni okulların açılmasında rol alan yazar, 1918'in ilkbaharında Suriye'den ayrılmıştır (Erdal, 2005, s.14-15). Tanınmış yazar Münevver Ayaşlı söz konusu faaliyetler çerçevesinde açlan okullardan birine devam eden isimlerden biri olmuştur (Çalışlar, 2011, s.278). Cemal Paşa, Halide Edip'in bahis edilen eğitim faaliyetleri ile ilgili olarak hatıratında şunları belirtmiştir:

“Türk kadınlığının övünç kaynă̆ı olarak takdir ettiğim Halide Edip Hanım Efendi'nin özel çaba ve yardımları sayesinde Beyrut'ta Deyru'n Nâsırat adı verilen Fransız kız okulu binasında ihya ettiğimiz yatılı kız lisesi ve öğretmen okulu ile Beyrut, Şam ve Cebel-i Lübnan'da kurduğumuz yatılı ve yatısız kız ilkokulları 
o kadar bir rağbet görmüştür ki, bazı aileler Amerika Kız Mektebindeki çocuklarım oradan alarak bu okullara vermeye başlamışlardı" (Cemal Paşa, 2012, s.323).

Halide Edip bölgeye gidiş amacı ile ilgili olarak bir soruya şu cevabı vermişti: "Suriye kızlarına iyi tahsil vermek, onlara Türk harsın telkin etmek, Suriye kadınlığı arasında müşterek duygular tesisine çalışmak. Ve bu mühim gayeleri elde etmek için hazırladığım programın tamamen tatbiki vaadini aldıktan sonra Suriye'ye gittim." (Erdal, 2005, s.54).

Halide Edip, bölgede açılacak okullar ile ilgili olarak az da olsa Anadolu'dan da bölgeye genç kızların gelmesini istemekteydi. Böylece eğitim paydasında, bir çatı altında birbirlerine yakınlaşmaları sağlanacaktı. Bu konuda da şöyle demekteydi: "Şam, Beyrut ve Cebel-i Lübnan muhasebe-i husûsiyyelerinin her birisi senede üç bin lira tahsisat vermeği taahhüt etmiştir, buna mukabil her sene bu üç yerden Dârülmuallimât için yirmişer ve sultanî kısmı için de, on beşer kız gönderilebilecektir. Şu halde her sene bu üç yerden gerek Dârülmuallimât gerek sultanî tahsili görmek üzere müessesemize yüz beş kız alınacak demektir. Bu yerli kızlardan maada, Anadolu'dan da, ücretleri mensup oldukları vilâyetlerden tesviye edilmek üzere, birkaç kız alacağız, Anadolu kızlarının Suriye'deki hemşireleriyle mektep sıraları üzerinde temas etmelerine bir ehemmiyet-i mahsusa atfediyorum; böyle bir temasin birbirimizi yakından tanımak hususunda icrâ edeceği tesiri uzun uzadıya izaha hâcet yoktur" (Erdal, 2005, s.56).

Halide Edip, Kız öğretmen okulu ve liseye öğrenci yetiştirmek için Şam ve Cebel-i Lübnan'da birer yatılı okul açılmasına önayak oldu. Beyrut'taki kız numune mektebinin yatılıya dönüştürülmesini de uygun gördü. Bölgede ilkokullarda eğitim üçüncü sınıfa kadar Arapça yapılmaktaydı. Halide Edip, genç kızların milli değerlerle barışık yetişmesine çok önem vermekteydi:

"Gerek sultanî ve Darülmuallimâtta, gerek numunelerde Arapça tahsiline ve kızlar Suriye'nin millî ve tabî̀ güzelliklerini hissedebilecek bir halde büyütmeğe itina ediyoruz" (Erdal, 2005, s.56).

Halide Edip makalelerinde ve romanlarında savunduğu, teşekkül etmesini istediği kadın tipi eğitimli, doğuya ve batıya aşina, modern aynı zamanda dindar bir kadın tipi idi. Esasen bu ideale en güzel numune bizzat kendisiydi (Ozansoy, 1964, s.3-22). 
Halide Edip'in düşüncesine göre kadınların evde dört duvar arasında yaşama zamanı geçmiştir. Onların hayata katılması gerekmektedir. $\mathrm{Bu}$ nedenle de eğitim almaları zorunludur. Kadınlarımızın eğitimi için adres Anglo- Sakson modeldir. İngiliz eğitim anlayışının hâkim olduğu kız mekteplerinin açılması gerekmektedir. Tabi bu noktada dikkat edilmesi gereken kızlarımızın manevi değerlerini koruyarak bu eğitimi vermektir. Örneğin tesettür korunarak da pekâlâ bu okullara devam edile bilinir (Tanar, 2013, s.166-167).

Halide Edip'e göre Osmanlı kadının eğitimsiz kalmasının veya istenen eğitimi alamamasının nedeni onları bu hususta kısıtlayan erkeklerdi. Ayrıca "Paşa babaların ahlaksız, az buçuk da kendi gözlerinin zevki için getirdikleri" mürebbiyelerin de pek faydası olmamıştı. Halide Edip, Isabel Fry'a yazdığı bir mektupta da mürebbiyeleri eleştirmekte, tek özellikleri batılı olmak olan ehliyetsiz mürebbiyelerden dert yanmakta onları ve verdikleri zararları şöyle özetlemekteydi:

"Zengin liberal fikirleri yaymaya başlamış yeni nesil kadınlar, okumuş bir azınliktan ibarettir. Kendilerine mürebbiye diyen, aptal ve değersiz mahlûklar tarafindan maneviyatı sakatlanmamış, az sayıdaki talihli kadınlardır bunlar" (Durakbaşa, 2017, s.203).

Bu durumdan kurtuluş reçetesi olarak da "Bizi İngiliz veya Amerikalılar gibi ciddi metin terbiyeler ile büyütünüz öyle mektepler açını" demekteydi (Halide Salih, 1324b, s.2-3).

Halide Edip, kadınların eğitimine büyük önem vermekteydi. Çünkü kadınlar, eğitilmeden kendilerine verilen hakların hiç birisinden faydalanması mümkün değildir (Ergün, 1996, s.150). O, kadını yetişecek neslin ilk öğretmeni olarak düşünmekteydi. Meşrutiyetten sonra bu idare için yeni insan tipi gerekmektedir. Yeni insan tipi için gereken iki şey ise; birincisi eğitim ve öğretim ikincisi ise bunu gerçekleştirecek öğretmen ve annelerdir. Zira hâlihazırda Türk kadını buna hazır değildi (Enginün, 1978, s.402).

Halide Edip'in kızların eğitimi faaliyetine bir katkısı da devrin ünlü eğitimcisi İngiliz, Isabel Fry'i, Türk kız okullarını incelemek üzere İstanbul'a davet etmesidir (Durakbaşa, 2017, s.191). Ad1 geçen yazar Türkiye'ye iki sefer gelmiş ve incelediği okullar hakkında bir rapor yazmıştır (Enginün, 1978, s.406). Bu raporun Türkçe çevirisi, Halide Edip tarafından Tanin'in 167. sayısında yayınlanmıştır. 


\section{Halide Edip'in Kız Öğretmen Okulu İle İlgili Düşünceleri}

Halide Edip'in, kızların eğitimi ile ilgili olarak üzerinde belki de en fazla durduğu okul Dârülmuallimâtdır. Maarif Nazırlığından Dârülmuallimât için rapor istenilen kişilerden biri de Halide Edip idi (Çalışlar, 2011, s. 91). Yazar kız öğretmen okullarını çok fazla önemsemekteydi. Gerçekten de kız öğretmen okulları kadın eğitimi tarihimizde fevkalade bir öneme sahipti (Altın, 2017, s.20-37).

Esasen Halide Edip'e göre kadınları eğitmek için işe iptidailerden başlamak gerekmektedir (Halide Salih, 1324c, s. 4). Ancak bu uzun vadeli bir iştir ve zaman kazanmak açısından önem verilmesi gereken Dârülmuallimâtlar yani kız öğretmen okullarıdır. Bu öğretmen okullarında yeni insan tipi için "taze" fikirlere yer verilmelidir. Hâlihazırdaki Kız Öğretmen Okulu'nu eleştiren Halide Edip, bu okulun bazı konularda rüştiye mekteplerinden daha geri olduğunu söylemekteydi (Şanal, 2004, s.655). Ona göre Dârülmuallimât'ın düzelmesi için yapılması gerekenlerden biri söz konusu okulların idarecilerini nitelikli insanlardan seçmekti. Bu konuda Tanin' de şunları yazmaktaydı:

"Ayşe Sıdıka Hanım istisna edilirse bu mektep o kadar acayip müdireler elinden geçmişti ki insan onların taht-ı terbiyesinde değil onlarla beraber aynı mahalde bulunmasın zül addederdi."

Halide Edip, mevcut haliyle Dârülmuallimât'ın genç kızlara faydası olmadığını hatta zaman kaybettirdiğini, evde oturmanın bu okula devam etmekten daha iyi bir tercih olacağını belirtmekte ve adı geçen okulu " $\mathrm{Ce}$ halet ve ahlaksızlık yuvası" diye nitelendirerek ağır biçimde eleştirmekteydi Bu Öğretmen Okulu'nun öğrencilere bir şey kazandırmadığını şu cümleler ile ifade etmekteydi: "Vapurlarda, şimendiferlerde, caddelerde bazı Dârülmuallimât'a giden hanım kızlara tesadüf edilir: bunların kıyafet-i hariciyeleri en müşkilpesent bir Müslüman'ı memnun edecek kadar kapalıdır. Fakat etvâr ve evzâları en hoppa bir frengi bile mütehayyir eder." Halide Edip'e göre bu "Yürümesini bilmeyen, birbirlerine çarparak sokağın ortasında kahkahalar salıveren" öğretmen adayı kızların davranışı ile "On iki on üç yaşında kısa fistanlı, saçları dökük, Beyoğlu'ndaki High School'a giden İngiliz kızlarının vakar ve ciddiyeti arasında ne kadar fark vardır" (Halide Salih, 1324c, s.5).

Halide Edip, Tanin gazetesinde yayınlanan makalesinde iyi bir kız öğretmen okulunun ne şekilde olması gerektiğine dair fikirlerini de ifade 
etmekteydi. Öncelikle okul müdiresi Amerikalı olmalı ve okulda Amerikan tarzı eğitim verilmeliydi. Bunun sebebini ise şöyle açıklamaktaydı:

"Amerikalılar sair-i akvâm-ı medeniden fazla bir şey öğretmemekle cidal-i hayatın her safhasına göğüs verecek, öğrendiğini daha sade ve basit yollarla öğretebilecek, sa'y ve ilmin hangi şubesine atılmak mecburiyeti karşısında olsa kendi çalışkanlığına güvenerek kolları bağlı durmayacak sahih, metin, faal adamlar yetiştiriyorlar."

Halide Edip'e göre kız öğretmen okulu merkezi bir yerde olmalı, dershanelerin içi aydınlık olmalı, okulda, kütüphane, Fen Laboratuvarı, spor salonu (Jimnastikhane), öğretmen odası bulunmalıdır.

Öğretmen okulu dört idadi dört rüştiye olmak üzere sekiz sınıf olmalıydı. Okulun eğitim dili Türkçe olmalı, yabancı dil mecburi ve İngilizce olmalı, hatta mümkünse bazı dersler İngilizce okutulmalıydı. Osmanlı Devleti'nin etnik yapısı göz önünde bulundurularak Bulgarca, Ermenice ve Rumca müfredatta yer almalıdır. Türkçe ve İngilizceden başka bir üçüncü dil, Fransızca veya başkası, zorunlu olmalıdır. (Halide Salih, 1324c, s. 5; Enginün, 1978, s. 405).

Rüştiye şubelerinde, üçüncü ve dördüncü senelerde "Diplomal bir terzi" tarafından haftada bir saat biçki-dikiş dersi verilmelidir. Yine aynı sınıflarda işinin ehli bir kadın tarafından uygulamalı olarak yemek pişirme dersi verilmelidir. İlk üç sene Rüştiye şubelerinde verilmesi gereken dersler şunlar olmalıdır: Hesap, Kıraat-1 Fenniye, Osmanlı tarihi (Muhtasar olarak), Türkler için Fransızca, diğerlerinin milliyetlerine göre Bulgarca, Ermenice, Rumca, Ulum-1 Diniye, Malumat-1 Medeniye, İktisat-1 Aile, Tarih-i İslam.

Dârülmuallimât'ın idadi kısmı ise Fen ve Edebiyat olarak iki ayrı şubeye ayrılmalı ve öğretmen adayları bu iki şubeden birini seçmelidir ler. İdadi kısmında Cebir, Hendese, Hikmet, Tarih-i Umumi, İlm-i Ahlak, Psikoloji ve Pedagoji dersleri mecburi olmalı, Müsellesat, Heyet, Sosyoloji, Tarih-i Tabî, Hıfzısıhha, Kimya, Sanayi-i Nefise, Felsefe-i Tarih gibi dersler seçmeli olmalıdır. Ayrıca müfredatta Musiki ve Resim dersleri yer almalıdır (Halide Salih, 1324c, s. 6).

Halide Edip, okul idaresinin başında "muktedir" bir müdür ve ona yardım eden iki muavini olması gerektiğini söylemekteydi. Çeşitli ders 
kitaplarının yazımı veya yabancı dillerden tercümesi işin ehli olan kimseler tarafından yapılmalıydı (Halide Salih, 1324c, s. 6; Enginün, 1978, s.405).

Halide Edip'in kız öğretmen okulunda yapılması gerekenlere dair fikirlerinin özetini adı geçen okulun daha kaliteli hale gelmesi için bazı maarif insanı isimler ile birlikte kendisinden de istenen rapordan anlaşılmaktadır. Ona göre okul ile ilgili aşağıdaki maddelerin hayata geçirilmesi gerekmekteydi:

1. Derslerin çoğu Arapça ve Farsçadır, bunun devamı gerekmekle beraber, daha yeni canlı bir dile, modern bir havaya ve teçhizata ihtiyaç vardir.

2. Yapılması gereken hayati değişiklik, Türk öğrencide yeni bir ruh geliştirmektir. Öğrencilere sorumluluk ve işbirliği duygusu, kendine güven, öğretmenlere açık fikirlilik, zorbalıktan kaçınma duygusu aşılanmalıdır.

3. Öğrencilere moral kazandırmak için jimnastik, müzik ve resim derslerinin verilmesi gereklidir.

4. Mektep gezileri tertip etmek. Yurt bilgisi ve coğrafya derslerinde yaşanan yerleri yakından tanıyarak öğrenmek; ezbere dayalı bilgiler vermekten daha faydalı olacaktır.

5. Ezberlenecek şiirlerin iyi seçilmesi ve öğrencilere yapmacık bir tavırla okutulmaması gereklidir (Sağlam, 2015, 70-71).

\section{Halide Edip'in Romanlarında Ĕ̆itime Dair Düş̧ünceleri}

Halide Edip'in romanlarındaki kadınlar geleneksel Osmanlı kadınlarından farklıdır. Bu kadın tipi "evlerinin süsü" ve erkeklerin saadetini gaye edinmiş tipler değil öğretmenlik, hemşirelik vb. gibi kendisine verilen her türlü görevi fedakârca ve ağırbaşlılıkla yapan, karakterli ve vatanın selameti için çalışan kadınlardır. Bütün memlekete bir anne olan kadınların en göze çarpan vasıfları bir şekilde eğitici olmaları idi (Başc1, 1999, s.78).

"Fertleri ve toplumu kökten değiştirecek amil eğitimdir" fikrine inanan ve edebiyatı bir manada buna aracı kılan Halide Edip, romanlarında da bu görüşünü başarıyla dile getirmiş, kadının eğitimi sorununa, çeşitli makalelerinin yanında, romanlarında da dikkati çekmiştir (Mutlu, 2017, s.130). 
Halide Edip'in Tatarcı romanında bir kampta toplanan gençlerden biri olan Haşim, kadının eğitim alması meselesine olumsuz bakar. Yazarın romanda ideal kadın tipi olarak işlediği Lale gibi kadınlar Haşim'in hiç hazzetmediği tiplerdir. Haşim'e göre eğitim için enerji ve zamanlarını harcayan hatta bu uğurda Avrupa'ya bile giden erkeklerin iş bulamamasının sebebi bu işlerde çalışan kadınlardır. Düşünce ve tavırlarıyla romanda örnek bir kahraman olan Lale'ye göre gençlerin görevi, kurulan yeni toplumun temellerini kuvvetlendirmek, eski düşünceler ve geleneklerle mücadele etmektir. Şüphesiz bu da eğitim ile gerçekleşecektir (Erdal, 2008b, s.115). Zaten Lale'nin kendisi de öğretmendir (Yllmaz, 2007, s.248).

Raik'in Annesi isimli romanında ise Halide Edip iki kadını kıyaslar. Bunlardan biri modanın etkilerine sınırsız açık Türk kızı Necibe diğeri ise inançlı Türk kızı Refika'dır. Burada idealize edilen Refika dindarlığının yanında eğitimi ile de öne çıkar. Fakat dindarlık bağnazlıktan arındırılmış bir din anlayışına sahip olmaktır. Yani yazara göre eğitim ile bağnazlığın aynı anda olması mümkün değildir (Karabulut, 2017, s.179-180).

Halide Edip'in, Sevda Sokağı Komedyası romanında da eğitim düşüncesine rastlamak mümkündür. Adı geçen romanda beslemelerin eğitimi ile ilgili olarak konağa bir hoca gelmektedir. Yeşil sarıklı, kara sakallı bir şahıs olan Hoca eski usule göre çocuklara Kuran okumayı öğretir. Hocanın eğitim anlayışı da doğal olarak modern değildir. Çocuklarda hocaya karşı saygıdan çok korku hâkimdir. Oysa talebe muallimini saymalı fakat bu saygı korkudan beslenmemelidir (Şahin, 2012, s.132).

Kerim Usta'nın Oğlu romanında da karşımıza yine siyah sakalı, yeşil sarığı ve sert bakışlı ile eski tip bir eğitmen çıkar: Ömer Hoca. O mektebin hemen üstündeki küçük odada ailesiyle yaşar. Hocanın elinde bir eğitim aracı olarak daima bir değnek bulunur. Sınıfta da öğrencilere gözdağı vermek için oturduğu yer minderinin ve büyük rahlesinin yakınında ucu sivri, kırbaca benzeyen uzun bir değnek asılı durmaktadır (Şahin, 2012, s.125). Bu romanda doğru eğitimi temsil eden kişi Doktor Kasım'dır. Amerika'da okuyan kahramanımız özellikle Fen derslerinin nazari olarak değil uygulamalı olarak verilmesini savunmaktadır. Tıp eğitiminin noksan ve yanlışlıklarını şöyle dile getirir:

"Bizde daha fazla nazari kısım hâkimdir. Orada ise, kuvvetle ve ısrarla hatta bazen mübalağaya kaçan bir tecrübe ve tetkik onların içinde bir çocuk tecessüsü 
kadar taptazedir... Bana, yıllarca dâhiliyeci olarak insanlarla temasım, insan denilen mahlûkun, hepsinin birbirinden başka olduğunu, beklemediğimiz aksülameller karşısında bıraktığını öğretmiştir" (Önertoy, 2011, s.42).

Eğitim, tekâmül vb. konular açısından İngiliz kadınının Türk kadınına örnek olabileceği fikrini savunduğu eseri Seviye Talip isimli romanında İngiltere'de tahsil gören Fahir'in eşi Macide eğitimsiz bir kadındır (Gözütok, 2010, s. 431; Karabulut, 2017, s.180). Felsefe eğitimi alan kocas1 Fahir, (Önertoy, 2011, s.42). Macide'yi değiştirmeye yani eğitmeye çalışır. Bunda başarılı olan kadın kitap okumaya başlar hatta yabancı dil bile öğrenir.

Handan romanında Refik Cemal eşi Neriman'ın okuma alışkanlığının çok az olmasından yakınır. Romanda kadınların da Sosyoloji, Tarih, Felsefe ve Edebiyat gibi disiplinlerde bilgi sahibi olması gerektiği vurgulanır (Şahin, 2008, s.99-126).

Toplumda bazı kimselerin içinde bulunduğu bağnazlıktan ancak eğitim ile aşılabileceğini düşünen Halide Edip'in bu düşüncesinin izlerini Yeni Turan'da görmek mümkündür. Yayınlanmadan önce Tanin gazetesinin çeşitli sayılarında "Yeni Turan, muharriri: Halide" başlı̆̆ıyla tefrika edilen Yeni Turan bir yönüyle eğitim ile ilgiliydi. (Tanin, 1912, No: 1435; Gözütok, 2010, s.411-412).

Yeni Turan romanında Finlandiyalıların, aydınların öncülügüünde, bataklıklardan bir "beyaz zambaklar ülkesi" yaratmasına benzer bir hareketlilik ile ülkenin kalkınması için girişim başlatan Oğuz, Anadolu'da okullar açar. İlköğrenimi zorunlu yaparak, Anadolu'da eğitimsiz vatandaş birakmaz.

Kadın hareketleri bakımından en önemli eseri sayılan ütopik romanı Yeni Turan'da kadının eğitimi meselesi de gündeme getirilir. Romanda kadınlar İstanbul dışında Erzurum'da okullar açmışlardı (Taşkıran, 1973, s. 58). Yeni Turan Partisi'nin başkanı Oğuz Bey kadınların eğitimi için yeni mektepler açılması, yeni eğitim fırsatları vb. için çeşitli yasa tasarıları hazırlamaktadır çünkü kadınların erkeklerle eşit bir eğitim özgürlüğü elde etmesi demek, ülkenin, on-on beş yıl gibi kısa bir sürede Finlandiya benzeri bir ülke olması anlamına gelmekteydi (Gözütok, 2010, s.441-442).

Söz konusu romanda yer alan Cuma okulları aynı zamanda Halide Edip'in eğitim anlayışını ortaya koymaktadır. Adı geçen eğitim kurumları 
tasarlanan yeni toplumun fertlerinin yetiştirildiği okullardı. Ahlaki terbiyenin de verildiği bu okullarda modern eğitimle halkın eğilimleri harmanlanmaktaydı. Genel olarak romanda eğitimden murat edilenin salt bilgi vermek olmadığı aynı zamanda halka da bir şeyler öğrettiği beyan edilmekteydi. Esasen Kaya ve Oğuzun en büyük gayesi de buydu (Şahin, 2010, s.263).

Döner Ayna romanı Halide Edip'in yazı hayatı göz önüne alındığında geç bir tarihte Demokrat Parti devrinde yazılmıştır. Fakat yazara göre bu devirde bile kırsal kesimde kadının eğitimine hoşgörü ile bakılmamaktadır. Köyün Ağası olan Hacı Murat, oğlu Hasan ile kızı Hanife'ye eğitim konusunda aynı davranmamakta, ayrımcılık yapmaktadır. Hatta Hasan'ın ders çalıştı̆̆ sırada Hanife'nin onun etrafında dolaşmasını bir şeyler öğrenmeye çalışmasını bile men etmektedir. Çünkü ona göre kızlara eğitim şart değildir. Onlar evine, çocuklarına ve erkeğe hizmet için yaratılmıştır.

"Evet, birinci haftadan sonra genç hayatını kurtaran bulutlar dă̆gldı. Bilhassa Hasan'ın muhabbeti, bütün varlı̆̆ın ısıtıyor; o Arapça fiilleri tekrar ederken hayranlikla dinliyor, bu garip sesli kelimeleri bu kadar kolaylıkla anlayan oğlan kardeş, ona kâinatın bir numarahı harikası gibi geliyordu."

İlköğretimdeki yanlış uygulamaların eleştirisi de Halide Edip'in romanlarında yer bulmaktaydı. Sonsuz Panayır'da şunlar dile getirilmekteydi:

"Bugün insanların kafasın ta ilköğretimden başlayarak, birbirine uymayan beş on felsefe ile gelişigüzel dolduruyorlar. Artık hiçbir kimse, herhangi bir kaide ve ideolojiyi doğru mu, yanlış $m \imath$ diye tetkike lüzum görmüyor, üstünde düşünmek zahmetine katlanmıyor"

Kendisi de evde özel dersler alarak eğitimini geliştiren yazar, okullaşmanın yaygınlaşmasıyla okulu evdeki eğitime tercih eder. Mev'ut Hüküm romanında, Sara'nın kızı Atıfe, eve gelen özel hocalardan ders almaktadır fakat bu durum çok verimli olmadığı için Atıfe yatılı okula verilir (Küçükgörmen, 2010, s.234).

Son Eseri romanında Dome de Sion'dan mezun olan Kamuran'in kişiliğinde aydın Türk kadını tarif edilmektedir. Zira genç kız, bir Hristiyan Katolik okulunda okumasına ve Hristiyanlık propagandasına maruz kalmasına rağmen hem eğitimini almış hem aydın bir Müslüman kadın olabilmiştir (Yılmaz, 2017, s.331-332). 
Halide Edip'in düşüncesine göre cumhuriyet sonrası Türkiye'de inşa edilecek modern hayatın ve milli kimliğin inşası için öğretmenler çok önemli rol oynamalıdır. Bu rolün önemi kurtuluş savaşını kazanan askerlerin oynadığı rolden daha az önemli değildir. Vurun Kahpeye isimli romandaki Aliye Öğretmen bu rol modelin öncüsüdür (Yavaş, 2017, s.106107).

Halide Edip'in belki de en fazla bilinen romanı olan ve istiklal harbimizi anlatan ilk roman özelliği de taşıyan eseri Ateşten Gömlek'teki Ayşe karakteri yabancı lisan bilen, eğitimli ve vatansever bir kadındır. Genç kadının eşi ve çocuğunu Yunanlılar katletmiştir. Ayşe, Sakarya savaşında hemşire olarak katılır nihayetinde kocası ve çocuğu gibi o da şehit olur (Y1lmaz, 2017, s.332).

\section{Halide Edip'in Talim ve Terbiye İsimli Eseri}

\section{Eserin İçeriği}

Halide Edip, Talim ve Terbiye isimli eserini İstanbul Kı Öğretmen Okulu'nda (Dârülmuallimât) öğretmenlik yaptığı sırada kaleme almıştır. Aslında eser, Amerikalı eğitimci düşünür H. Harrell Horne'un The Psychological Principle of Education isimli eserin Türkçeye tercümesidir. Fakat esere ülkenin ihtiyaçları doğrultusunda eklemelerde bulundu (Erdal, 2008c, s.89). Sonuçta ortaya çıkan eser salt bir tercüme eser değildir (Ergün, 1996, s.212-213). Bu konuda eserinin mukaddimesinde:

"Talim ve terbiye ile meşgul olmadan evvel bu ilme ait en çok dikkatle tetkik ettiğim Platon'un Cumhuriyet'i, J. J. Rousseau'nun Emil'i, Vorner'in, K. Patrik'in "Fenn-i Etfal"leri ve bu esaslar üzerine yazılmış bir takım tarihi ve tenkidi asâr oldu. Fakat bunlar arsinda ilm-i ruhla ilm-i talimin arasıdaki münasebet-i ameliye ve maneviyeyi en vazh surette toplayan muallim Horne'un "ilm-i Talimin Psikolojik Esaslar" ismindeki eserini buldum. İlm-i Talimin usulünü tamamıla kendisinden iktibas ettim. Muhitimiz ve ihdiyacat-ı tekâmülümüz için nazar-ı itibara alınacak nakatı kendim tayin ettim" diyen Halide Edip, bu eserin Dârülmuallimîn ve Dârülmuallimât öğretmenlerine ve diğer meslektaşlarına faydalı olacağı kanısındaydı (Halide Edib, 1327, s. 4). 
Halide Edip, tercüme edeceği eseri seçerken, psikolojik bir eser olmasını tercih etmişti. Zira ona göre, nasıl sanayi kimya ilminden, tıp bakteriyolojiden, ticaret iktisat ilminden can bulmuşsa, eğitim de psikoloji ilminden can bulmaktaydı (Ergün, 1996, s. 212-213).

Halide Edip, kitabında Horn'a yazdığı bir mektuba da yer vermiştir. Söz konusu mektupta Horne'a takdir duygularını belirterek eserin genç Türk öğretmenlerine rehber olduğunu belirtmekteydi (Halide Edib, 1327, s. 5-7).

Halide Edip, eserine "usul-i talim ve terbiye ilim midir?" Sorusuna yanit arayarak başlamıştır. Cevap olarak ise kimya, ilm-i nebatat, ilm-i hayvanat, mantık, ilm-i ahlak birer ilim olduğu gibi usul-i talim ve terbiyenin de bir ilim olduğu sonucuna varmıştır. Ona göre talim ve terbiye bir ilim olmanın yanı sıra aynı zamanda bir sanattır (Halide Edib, 1327, s. 4-5). Halide Edip bu konudaki gerekçesini şöyle açıklamaktaydı:

"Talim ve terbiye cemiyet-i beşeriyenin bir müesesesidir ki mektep vasıtasiyla efradını kabiliyetleri dâhilinde tekâmül ettirir. Sanatı ilimden tefrik eden şey, sanatın bir amel olmasıdır. Sanatlar cemiyetin maksadını vücuda getirmek için sarf ettiği emeklerdir. Sanat-ı harp sanat-ı ticaret vesaire hep bu kısma dâhildirler. Talimin sanat olduğu ise aşikârdır. Çünkü talim ve terbiye de cemiyetin maksatlardan birini vücuda getirmek için sarf ettiği bir emektir. Cemiyet nasıl iktisab-ı servet ederek efrâdına dağıtıyor, hastaların tedavi ettiriyor, canileri ıslaha çalışıyor ise çocuklarına da öylece bir talim ve terbiye veriyor. Binaenaleyh talim ve terbiyenin bir ilim olup olmadığın tetkik ederken bir sanat olduğunu nazardan dûr tutmamalıdır. Mademki talim ve terbiye cemiyetin bir maksadın husule getirmek için sarf edilen bir emektir. Bu halde buda bir sanattır ve mademki talim ve terbiyeye müşabeheti bulunan sanayi ayn zamanda birer ilimdir. İlim ve terbiye de bir ilimdir. Bir muallim sanay-i beşeriyenin diğer mütehassislarından tefrik edilemez; onun da bina-yı sanat ettiği Kavanin-i ilmiye vardır. Hülasa talim ve terbiye evvelâ bir sanat, saniyen bir ilimdir" (Halide Edib, 1327, s. 3-5).

Halide Edip, bazı ilimlerin talim ve terbiyeye yardımcı olduğu kanaatindedir. Bu ilimlerden biri tarihtir. Mevcut neslin çocuklarının mazinin çocuklarından büsbütün ayrı terbiye edilemez bu konuda tarih bize yardımcı olmaktadır.

Tarih sayesinde talim ve terbiye konusunda geçmişte öğrendiklerimiz, gelecekte nasıl bir talim ve terbiye istediğimiz konusunda bizi aydınlatır. 
Geçmişin hatalarından ders almamızı sağlar. Geçmiş milletlerin kullandıkları talim ve terbiyeyi incelemek günümüzde ortaya daha kullanışlı ve daha orijinal talim ve terbiye metotları koymamızı sağlayabilir (Halide Edib, 1327, s.19, 22-23).

Usul-i talim ve terbiye için dört şey lazım olduğunu belirten Halide Edip, bunları şöyle sıralamaktadır:

1. Öğrenci: Öğrenci, eğitim ve öğretimin merkezidir.

2. Program: Öğrenciye öğretilen şeylerdir.

3. Eğitim-öğretim çevresi: "İnsan nerede olursa olsun bir şey öğrenebilir." Fikri bu gün geçerliliğini yitirmiştir. Okul binası, bahçe, kütüphane vb. yerler ne kadar güzel ve kullanışlı olursa eğitim-öğretimin kalitesi de o nispette artar.

4. Öğretmen: "Muallim hayat ortağıdır." Tecrübeli ve bilgili öğretmenlerin öğrencilerin hayatında büyük tesirleri vardır.

Talim ve terbiyede istenilen başarıyı yakalamak bu dört faktörün "Aheng-i tabii" sine bağlıdır (Halide Edib, 1327, s.25-26). "Hayatın en güzide hislerini, fikirlerini, şakirtlerine ilka etmeği bilen bir muallim veya muallime vazifesini anlamış demektir." (Halide Edib, 1327, s.27) Eğitim ve öğretimin başarıya ulaşmasında öğretmen birinci derece de sorumludur.

"Cidden büyük bir muallim" iyi bir program tanzim eder, eğitim öğretim de öğrencilere yüksek bir gaye aşılar. Öğretmenlerin en büyük gayesi öğrencilerin tekâmülünü sağlamak olmalıdır. Öğretmen, öğrencinin dimağı ile konular arasında bir vasıtadır. Öğrencinin kapasitesini iyi bilmeli ona göre hareket etmelidir. "Muallim ilmi talebenin nazarında yavaş yavaş büyütür tekâmül ettirir."

Halide Edip, öğretmen öğrenciye yalnızca okulda müfredat bilgileri vermez. $\mathrm{O}$, aynı zamanda öğrenciye günlük yaşam hakkında bilgi verir. Onu hayata hazırlar:

"Muallim müfessir-i hayattır. Hayat büyük bir sanattır. Tecrübesiz olan talebe hayatı bilmez. Ona muallim hayat-ı tefsir eder. Muallim kendi hayatı ve talebesine olan rabıtasıla hayatın iyi ve fena şeylerini şerh eder. Hayatın büyük hakikatlerini çocuklarm lisanına tercüme eder." 


\section{Eserde Öğretmenlere Tavsiyeler}

Öğretmenin görevinin çok zor ve çok önemli olduğunu belirten Halide Edip, öğretmenin birtakım vasıflara sahip olması gerektiğini bu özellikleri taşımayan öğretmenlerin derhal istifa etmeleri gerektiğini istemekteydi. Halide Edip'in öğretmende var olması gerektiğini istediği vasıflar şunlard1:

1. Öğretmen öğrettiği konu hakkında etraflı bilgi sahibi olmalıdır: Öğretmen bilmediği bir şey hakkında öğrencileri aydınlatması mümkün değildir. Eflatun, "İnsan kendinde olmayan bir şeyi başkasına veremeyeceği gibi, bilmediği bir şeyi de başkasına öğretemez" demiştir. Bir öğretmen bildiklerini çocuklara öğretemeyeceğinden her halde öğrettiğinden fazla bilmelidir. Konuyu iyi bilmek öğretmene şevk verir. Bilen öğretmen sınıfa coşkuyla girer. Bu coşku öğrencilere de sirayet eder. Müfredata hâkim bir öğretmen kendinden emindir (Halide Edip, 1327, s.35 ).

Okutacağı konuları iyi bilmeyen öğretmen derste sinirli olur. Öğrencilerin sorularından korkar. Mevzu haricindeki soruları bilmediğinde bile mahcup olur. Oysa konuya hâkim bir öğretmen "Bilmiyorum" demekten imtina etmez.

Resim, musiki ve beden eğitimi gibi derslerin öğretmenlerinin öğrenciye yapmalarını istedikleri şeyleri kendilerinin de yapabilmeleri gerekir.

Alanında yetersiz öğretmenlerin derslerin mühim yerleri ile ehemmiyetsiz yerlerini takdir edemeyeceğini söyleyen Halide Edip, dersi resim tablosuna benzetir. Nasıl ki bir resim tablosunda öne çıkması gereken parçalar olduğu gibi öğretmende kara tahtanın başına geçtiği zaman bunu yapabilmelidir. Konuyu bilmeyen öğretmen ise dersin neresinin önemli olduğunu takdir edemeyeceğinden tahtayı da verimli kullanamaz (Halide Edib, 1327, s.36). Bu tip öğretmenler hürriyet olmayan memleketlerde bulunabildiğini savunan Halide Edip, II. Abdülhamit devrinde bu tip öğretmenlerin daha fazla bulunduğunu ileri sürmekteydi.

2. Öğretmen öğrencilerini çok iyi tanımalıdır: Öğretmen öğrencileri, şahsi ve genel olarak iki türlü tanımalıdır. Öğretmen, öğrenciyi şahsen tanıması için sadece sınıf ortamı yeterli olmaz. Teneffüs aralarında, bahçede hatta sokakta bile öğretmen öğrenciyi tanımak için fırsat kollamalıdır. İnsanların hepsi şahıs olarak tanınmak, kendisine adıyla 
hitap edilmesini ister. Öğretmenin öğrenciyi tanıması öğrenci üzerindeki etkisini artırır. Öğretmen öğrencinin hareketlerini takip edebilmek, onu uyarabilmek için de öğrenciyi tanıması gerekmektedir.

3. Öğretmek kabiliyetine sahip olmak: Öğretmen olabilmek için alan bilgisi, öğrenciyi tanımak gibi özelliklerin kifayetsiz olduğunu belirten Halide Edip, öğretmenin "Öğretebilmek iktidarına" sahip olması gerektiğini belirtmekteydi. Ona göre bu kabiliyetin iki kaynağı vardı. "İrsi diğeri kesbidir. Cidden büyük bir muallim büyük olarak doğmuştur." Gerçi bazen bir öğretmeni talim ve terbiye de büyütebilir fakat doğuştan yetenekli olmak daha mühimdir.

Kabiliyetli bir muallim usul-i tedris eğitimi almadan da faydalı bir şekilde ders işleyebilir. Ama kabiliyetten mahrum olan bir öğretmenin pedagoji eğitimi almadan bunu başarabilmesi mümkün değildir. Her öğretmeninin fenn-i usul bilmesi ve onu kullanması gerektiğini savunan Halide Edip, bunun gerekçelerini şöyle sıralamaktaydı:

Öncelikle ders okuturken yöntem ve metottan vazgeçmek mümkün değildir. İkinci olarak mademki öğretmen usulden vazgeçemiyor en iyisini bilmek ve uygulamak zorundadır. Halide Edip, ders okutma yöntem ve tekniklerini kullananlar için şu tavsiyelerde bulunmaktaydı:

"Evvela eğitici şunu bilmelidir yöntem ve teknik işin kabuğudur, özü ise öğretmendir. İkinci olarak, sınıf usulü his etmeli fakat görmemelidir. En önemlisi de öğretmen kullanılan yöntem ve tekniği iyi takdir edebilmeli gerekirse değiştirebilmelidir."

4. Öğretmen güzel ahlak sahibi olmalıdır: Öğretmende güzel ahlak elzemdir. Öğretmen çok yüksek ahlaki vasıflara sahip olmalıdır. Dürüst olmalı, öğrencilerden birini diğerine karşı kayırmamalıdır. Hata yapan en sevdiği öğrencisi de olsa uyarmalı ve onu düzeltme yoluna gitmelidir (Halide Edib, 1327, s.39-41).

Halide Edip, çocukları eğitirken ebeveyn, öğretmen vb. büyüklerin onlara örnek olması gerektiğini düşünmekteydi. Örneğin küfür eden çocuklar anlamını dahi bilmedikleri bu kelimeleri büyüklerinden öğrenmektedir. Büyüklerin küfreden çocukları azarlarken yine argo ve küfüre başvurulması tam bir çelişkidir. Yazara göre hayâ ve iğrenmek bir medeniyet için temel kavramlardandır. Memleket için zaruri bu kavramlar çocuklara belletilmelidir (Çopur, 2010, s. 62). 
Halide Edip'e göre öğretmenin bilmesi gereken konulardan biri de ilmi ruh yani psikolojidir. Psikoloji bilmek öğretmene birçok kolaylıklar sağlar (Şanal, 2005, 151). Öğretmen öncellikle psikoloji sayesinde öğrencileri iyi tanıma fırsatı bulur. Öğrencinin zihninin tekâmül devrelerini psikoloji yardımı ile öğrenir ve buna göre hareket eder. Öğretmen, psikoloji sayesinde vücudun beyin ile olan münasebetini, hafızanın özeliklerini, çocuktaki iradenin muhtevası gibi kısaca "Çocuğun vazâif-i zihniyesinin elifbası ad edilen şeyleri öğrenir" (Halide Edib, 1327, s.45-46). Öğretmen, "Nazari" değil "Ameli" psikolojiyi öğrenmelidir. Aksi takdirde zaten "Pek çok meşgul olan muallimler" boşuna zaman harcayabilirler. Psikoloji öğrenmeyi öğretmene şahsi olarak da faydalı bulan Halide Edip, bu ilim sayesinde öğretmenin kendini ve çevresini daha iyi tanıyabileceğini savunmaktaydı. Ayrıca bu ilim sayesinde öğretmen, ders okuturken tercih ettiği yöntem ve tekniklerin öğrenciye yarar sağlayıp sağlamadığını kimseye sormadan kendisi değerlendirebilir (Halide Edib, 1327, s.50-51).

Halide Edip' in düşüncesine göre bir öğretmenin çalışmasında yüksek netice almasının ilk adımını "Mağlup olmayacağım, adil, doğru ve çalışkan olacă̆ım" diye kendi kendine bir karar vererek atabilirdi (Halide Edib, 1327, s.65).

Öğretmen koleksiyonu da bir eğitim aracı olarak kullanabilir. Bu koleksiyonlar bitkilere ve hayvanlara ait olabilir. Bu hadisede öğretmenin dikkat etmesi gereken şey bu işi öğrencilerin bizzat kendilerinin yapmasıdır (Halide Edib, 1327, s.75).

Öğretmen işleyeceği konu ile ilgili hazırlık yaparken en ehemmiyetli noktaları ayırmalı ve dersin esasını teşkil eden bu noktaları bir mantık çerçevesinde birleştirmelidir. Öğretmen derste müphemiyete yer vermemeli anlattığı konularda net olmalı öğrencinin de öyle olmasını sağlamalıdır (Halide Edib, 1327, s.84).

Öğretmen ders işlerken öğrencinin merakını diri tutmalıdır diyen Halide Edip, öğrencinin merak duygusunun iki şekilde ortadan kalkacağını savunur; birincisi eski ve tekrar edilen bilgi, ikincisi ise öğrencilerin anlamadıkları bilgiler. Dolayısı ile öğrenciye anlayabileceği yeni şeyler sunulmalıdır. Öğretmen, bir öğrencinin "Seviye-i irfanına" göre konuları izah etmelidir. Bu ne kadar müşkül ise o kadar elzemdir. Öğretmen, çocuklardan yaşlı olduğunu unutup, çocuklar gibi düşünmediği sürece onlara bir şey öğretmez (Halide Edib, 1327, s.92-94). 
Öğretmenin, öğrencilerin anlamadan ezberlemelerine mani olmaları gerektiğini düşünen Halide Edip, bu konuda şu örneği vermekteydi:

"Vaktiyle çok ezberci olan bir muallimin şakirdine dersini anlayıp anlamadı̆̆ını sormuşlar 'O kadar şey öğreniyoruz ki anlamaya vakit kalmıyor' demiş" (Halide Edib, 1327, s.102). Ancak bazı konuların ezberlenebileceğini belirten Halide Edip, bu konuda öğrencinin söz konusu formülleri anlayarak ezberlemesini şart koşmaktaydı. O, bu konuda şunları dile getirmekteydi:

“Bize kalırsa deriz ki kaide vazıh bir suretle yazılmış da bunu talebe anlamışsa onu ezberlemede beis yoktur. Anlaşılmayan kaideleri katiyen ezberlememeli; şakirt kendi lisanıyla izah etmeli. Vicdan kaidelerin manasın muhafaza etmeli. Istediği zaman kendi lisanıyla tekrar edebilmeli; En açık ezberlenmiş kaideleri bile talebe kendi lisanı ile tekrar edebilmelidir. Bir nazariye-i hendeseyi talebe ezberden ispat edebilmelidir" (Halide Edib, 1327, s.106).

Halide Edip, öğretmenden önem vermesini istediği diğer bir konu ise öğrencilerin hayal güçlerine önem vermesi ve bunu güçlendirecek tedbirler almasıydı. Bunun için öğretmen, öğrencilerin hayal güçlerinin nevilerini ve özelliklerini bilmelidir. Çocuklar hayal ile hakikat arasındaki farkı bilmezler. Onların mübalağaları yalan değildir, öğretmen bunun farkında olmalıdır (Halide Edib, 1327, s.110).

İnsanın muhayyilesini üçe ayıran Halide Edip, bunların çocukluk, gençlik ve olgunluk çağına ait olduğunu savunmaktaydı. Ona göre çocukluk devrinin muhayyilesini terbiye eden, tekamüle erdiren onu kişinin sonraki yaş devirlerine sağlıklı aktaran ve "Rabt eden" öğretmen olmalıdır (Halide Edib, 1327, s.116-118). Halide Edip'in fikrince öğretmenin bunu başarabilmesi için evvela kendisinin muhayyile sahibi bir insan olması gerekir. Zira hapishane müdürleri gibi davranan mektep müdürlerinin ve hocalarının zamanı geçmiştir. İhtiyacımız olan ince, hayal sahibi fakat aynı zamanda iş görebilecek öğretmelerdir. Halide Edip, bu bağlamda şöyle devam etmekteydi:

"Talebesinin istidadın ta'in eden bir resim muallimi, musikide en istidatlısın seçen musiki muallimi, müstakbel bir muharririn muhayyilesini terbiye eden bir edebiyat muallimi cidden büyük bir muvaffakiyete nail olmuş demektir" (Halide Edib, 1327, s.123-124).

Tasvir yeteneğini idrakten üstün gören Halide Edip, öğretmenlere bu konuda da şu öğüdü vermekteydi: 
"Muallimler talebesini kuvve-i tasvire malik bir dimağ ad etmeli, belki tasvirleri uyandırılacak, terbiye edilecek birer zekâ oldukların kabul ile ona göre talim ve terbiye etmelidirler" (Halide Edib, 1327, s.128).

Öğretmen, öğrencilerin her hangi bir eşyayı iyi tarif etmelerine dikkat etmeli, "Parlak ve vazıh" tarif yapmaları öğretilmelidir. Yapılan tariflerin sağlıklı olabilmesi için öğretmen öğrettiği şeye tarifle başlamamalı evvela olayları tetkik ettirmeli, sonra tasvir ettirmeli ve nihayet tarif etmelidir. Diğer bir deyişle bir şeyi evvela idrak, sonra tasvir ve nihayet tarif etmelidir. Mesela öğretmen küçük bir sınıfa atı tarif edecekse öncelikle imkânı varsa gerçeğini yoksa birkaç resmini göstermeli, en nihayet çocuğa atın ismini öğretmelidir (Halide Edib, 1327, s.132).

Halide Edip, öğretmenlerden istediği diğer bir hadise de öğrencilerin muhakeme güçlerini geliştirecek tedbirleri almaları idi. Ona göre bunun için de öğretmenin yapması gerekenler şunlardı:

"Parayı kazanmaktan ziyade suret-i sarf nasıl daha mühim ise malumattan ziyade suret-i sarf, tatbiki mühimdir. O halde öğrettiği mevzudan ziyade öğrenen talebeye ehemmiyet vermeli ve talebeye malumatı ve tecaribi üzerine mutlak muhakeme yürütmelidir" (Halide Edib, 1327, s.139).

Öğretmen öğrencilerin muhakeme güçlerinin gelişmesini engellememek için onları hür düşünmeğe alıştırmalı, kendi düşüncesini mutlak öğrenciye kabule çalışmamalı, onları düşüncelerinde serbest bırakmalı ve onları düşüncelerini ifade etmede desteklemelidir. Halide Edip'in, öğretmenlere bir tavsiyesi de ders kitapları konusundaydı. Ona göre kitap bir rehberdir ve öyle olmalıdır. Katiyen ezberlenecek "Bir emir" olmamalıdır. Bir öğretmen okutulan ders kitabıyla bazı konularda da olsa hem fikir değilse bunu sınıfta dile getirme cesaretine sahip olmalıdır. "Hakiki bir muallim kitap muallimi değil, hakikat muallimidir." Kitap öğretmenin yalnızca bir aracı olmalıdır (Halide Edib, 1327, s.139-140).

Öğretmen, öğrencilerin duygu boyutuna da önem vermeli, onlardaki var olan güzel hislerin gelişmesine yardımcı olmalıdır. Elbette öğretmenin öğrencilerden güzel şeyler hissetmelerini istemesinin bir faydası olamaz. Ama öğretmen dersler vasıtasıyla "İyi hisler vücuda getirecek şerait husule getirmelidir"

His terbiyesinde öğretmenin taklit ve misale yer vermesinin yararlı olacağını söyleyen Halide Edip, sözlerini şöyle sürdürmekteydi: 
"Bir muallim tekâmül ettirmek istediği hisleri talebesine göstermelidir. Muallim kendisinde olmayan bir fazilet veya hissi talebesine gösterir ise onlarm üzerindeki nüfuzu tenakus eder" (Halide Edib, 1327, s.172-173).

Halide Edip, öğretmenlerin yaptıkları işten zevk almalarını ve öğrenciye de dersi ve okulu sevdirmelerini istemekteydi. Öğrenci, öğretmeni saymalı fakat ondan korkmamalıdır aksi takdirde öğretmenin çabaları boşa gider. Öğrenciler için okul bir "Mevki-i zevk" olmalıdır. Zira öğrenci, paylaşmak, dostluk vb. mukaddes şeyleri okulda öğrenir (Halide Edib, 1327, s.178).

Eserinde ceza ve ödül konularına da değinen Halide Edip,öğrencilerin yaptıkları iyi davranışın karşılığında ödül, kötü davranışın karşılığında ceza görmelerini istemekteydi. Ona göre öğretmen "Fena bir harekete göz yumduğu gün mektepte intizam ahlakı bozulmuş" demektir (Halide Edib, 1327, s.180).

Halide Edip, öğretmenin öğrencilerinden şefkatini esirgememeleri gerektiğini belirtmekteydi. Bununla beraber öğretmenlerin şefkat duygularının takdir görmemesinin öğrencilerin bazı ahlaklarını bozacağı kanaatindeydi (Halide Edib, 1327, s.198).

Halide Edip'in fikrince öğretmenlerin görevlerinden biri de öğrenci nin güzel sanat ve estetik duygularını geliştirmek ve terbiye etmektir. Bu konuda öğretmenin ilk maksadı öğrencilerin sanat eserlerinden hoşlanmalarını sağlamaktır. İkinci maksat güzel sanatı ve sanatçıyı takdir ettirmektir. Son maksat ise onların sanatçı yönlerinin açığa çıkmasına yardımcı olmaktır (Halide Edib, 1327, s.201-202).

Halide Edip, öğretmenin bunları başarabilmesi için kendinsin de sanatı sevmesi, bir estetik anlayışa sahip olması gerektiğini ileri sürmekteydi. Öğretmen parasının ve zamanının bir kısmını güzel resim, musiki vb. harcamalıdır (Halide Edib, 1327, s.213) Halide Edib, "Seviyye Talip" isimli romanında menfi öğretmen tipine örnek verdiği Sultani'de Tarih öğretmeni olan Talip Bey güzel sanattan anlamayan, "boş kafall, duygusuz" bir insand1. 


\section{Sonuç}

Halide Edip, II. Abdülhamid devri İstanbul'unda doğmuştur. Uzun sayılabilecek yaşamında II. Meşrutiyet devrini, I. Dünya Savaşını, mütareke dönemini, Kurtuluş Savaşını, Cumhuriyetin ilk yıllarını, çok partili yönetim denmelerini tek parti dönemini, çok partili yılları yaşamıştır. Yazarın yaşadığı zaman dilimindeki kadınların yaşantılarına, özelliklerine siyasetten ve sosyal hayattan uzak duruşlarına baktığımızda onun hikâyesinin çok özel olduğuna kanaat getirilir. Aslında onun yaşadığı dönem örneğin II. Meşrutiyet ve hemen sonraki yıllar çok çalkantılı bir dönemdir. Savaşlar, yenilgiler, işgaller, yeni fikirler daha doğrusu yeni arayışların olduğu fevkalade yıllardır. Böyle olağan üstü bir devirde yaşayıp olanlara kayıtsız kalmak Halide Edip gibi yaratılışta olanlar için çok zordu. Nitekim o da bilfiil elinden geleni yapmış hayatın birçok alanında var olmaya çalışmıştır. Sivil toplum kuruluşlarında kurucu heyetlerde yer almış, gazete ve dergilerde çeşitli konularda yanlış bildiği konularda fikrini çekinmeden yazmış, I. Dünya Savaş'ında devlete yardımcı olmak adına elinden geleni yapmıştır. I. Dünya Savaş'ı yenilgisinden sonra başlayan işgallere karşı sesini en üst perdeden yükseltenlerden biri Halide Edip'tir. Zira bugün hala Sultan Ahmet Mitingi denildiğinde ilk akla gelen isimdir. Kurtuluş Savaşı'na da bizzat katılmış, savaş sırasında çeşitli vazifeler ifa etmiştir.

Çok sayıda kitap ve makale kaleme alan Halide Edip, ilk gençlik yıllarından itibaren yaşadığı her döneme dair söyleyecek sözü yazacak satırı olmuş bir aydındı. Eserlerinin önemli kısmını romanları oluşturur. Fakat birçok alanda eser vermiş olan yazar eğitim konusunda da eserler vermiş hatta bu alanda başta öğretmenlik, müfettişlik olmak üzere çeşitli vazifeler icra etmiş, bizzat sahada olmuştur. En çok roman alanında ürettiği eserlere baktığımızda da bir şekilde konuyu eğitime getirdiğine bu konudaki görüşlerine yer verdiğine şahit oluruz.

Halide Edip, Anglo- Sakson eğitim tarzının faydalı olacağına inanmaktaydı. Bu eğitim sistemiyle yetişen gençlerin pratik düşünen, kendine güvenleri olan faal bireyler olacağını ileri sürmekte ve bu şekilde Türkiye'nin geri kalmışlık durumunu kaderimiz olmaktan çıkarabileceğini umut etmekteydi. Onun bu konuda dikkat çektiği bir husus da gençlerin batı tarzında eğitim almalarına rağmen öz değerleri korumaları gerektiği 
idi. Misal kılık kıyafet tercihini İslam inancına göre yapmış bir genç kızın batı tarzı modern eğitim almasında bir beis yoktu.

Kız öğretmen okulunda eğitim bilimi dersi veren Halide Edip, pedagojik eserini kaleme alırken Amerikalı eğitimci H. Harrell Horne'nun eserinden faydalandı. Fakat onun özellikle batılı yazarlardan konu ile ilgili çok sayıda eseri incelediğini yine kendi kaleminden öğreniyoruz.

Halide Edip eğitim ile ilgili eserinde öğretmenlerin ve öğretmen adaylarının bilmesi gereken birbirinden farklı konulara değinmiştir. Eser eğitim işi ile uğraşan insanlara ders anlatma yöntem ve tekniklerinin yanı sıra öğrencinin eğitimi ve onun nasıl topluma faydalı iyi bir birey olmasının mümkün olacağına dair sorulara da cevap aramaktaydı.

Eğitimcilik mesleğini çok önemseyen Halide Edip'e göre öğretmen, öğrencinin zihninin yanında ruhunu da tekâmül ettirir, ettirmelidir. Dünyada gelinen noktada maddi gücün yerini zihin gücü almıştır. Bu güçle icat edilen silahlar en büyük orduları dize getirmiştir. Ona göre bunu geç fark etmemiz bizi asırlarca geri bıraktı. Bu noktada görevin öğretmene düştügünü söyleyen Halide Edip, öğretmenin yaptığ1 işin bilincinde olması gerektiğini, vazifesini kendisinin takdir etmesi lazım geldiğini belirtmekteydi. 


\section{EXTENDED ABSTRACT}

\section{The Idea of Education in Halide Edip's Works and Her Work "Teaching and Education"}

Hamza Altın

Bingöl University

Halide Edip married her first husband, Salih Zeki at a young age. She had two sons in this nine-year long marriage. She had to fled to Egypt due to death threats during the March-31st Events. After the situation was stabilized in the country, she returned to Istanbul and started teaching at the first teacher training school for girls in the Ottoman Empire. From then on, she focused on educational studies. She particularly conducted studies on girls' education. During this period, she also worked as an inspector at Religious Foundation Schools for Girls, which she mentioned in her memoirs stressing their benefits in learning about the people.

During World War I, upon the invitation of Cemal Pasha, she travelled to Syria and Lebanon for educational studies. When she was in Syria, she married Adnan Adıvar. Halide Edip started teaching and wrote on her educational ideas for the first time during the Second Constitutional Monarchy era. In these years, there was no stability in the country. This was also true for education. The Minister of Education has changed for eighteen times until the Armistice period. Sixteen of these ministers served less than a year. The most significant performance was that of Emrullah Efendi among these ministers.

Halide Edip tried to emphasize the educational problems in the Ottoman Empire until the fall of the empire. For example, in an article published in 1918, she stated that in many respects, the situation in Anatolia was not all right. One of the issues she mentioned was education. She emphasized that there were not enough teachers even in Istanbul and education was inadequate.

Halide Edip traveled to England due to an invitation by Isabel Fry. There, she conducted observations on several topics, especially education. In England, she communicated with the intellectuals, and thus her ideas matured. The fact that the educational system that Halide Edip idealized 
in her works was influenced by the British education system was a result of her own training, as well as the above-mentioned trip.

According to Halide Edip's ethos, women and men are intertwined and abreast in the society. Therefore, her educational approach was also shaped within this framework. In her opinion, it is important to start by training the woman, especially in order to achieve the above-mentioned ideal. Men and women should take on similar roles in life. The quality of the social structure is based on the education of women. Thus, the author believed in co-education. Furthermore, she believed that the lack of national awareness among women should be acquired through education.

Halide Edip also conducted educational activities in Syria. In 1916, upon an invitation by Cemal Pasha, he traveled to Syria with a group of intellectuals upon receipt of negative reactions on the Armenian conference she participated at Turkish Hearts Association. In the spring of 1918, she left Syria after working at schools and orphanages and playing roles in foundation of new schools.

According to Halide Edip, it was necessary to initiate the education of women in primary schools. However, this was a long-term goal and the teacher training schools for girls (Dârülmuallimât), should be prioritized to save time. Fresh ideas should be included in these teacher training schools to create a new type human. Halide Edip, who criticized the current Teacher Training Schools for Girls, stated that this school was more backward when compared to some other schools. According to her, one of the things that should be done to improve teacher training schools for girls was to appoint qualified administrators to these schools.

Halide Edip, who argued that inadequate teachers in their field could not differentiate important and unimportant topics in their courses, likened a course to a painting. Just as there are significant pieces in a painting, the teacher should be able to do the same on the blackboard. A teacher, who is not proficient on the topic, could not use the blackboard efficiently since she or he does not know the significant topics in the course. Halide Edip, who argued that such teachers could be found in non-free countries, emphasized that this type of teachers were the majority during the reign of Abdelhamid II.

Halide Edip believed that the grown-ups such as parents, teachers, etc. should be role models during the education of children. For example, the 
children who swear learn these words that they do not even know the meanings of from their elders. The use of vulgarism when reprimanding children is a complete contradiction. According to the author, shame and disgust are the basic concepts in a civilization. These concepts that are necessary for the nation should be instructed to the children.

According to Halide Edip, teachers should also be competent in psychology. Psychology knowledge provides several conveniences for the teacher. The teacher learns about the students through psychology initially. The teacher learns the evolutionary cycles of the student mind through psychology and acts accordingly.

Halide Edip, who stated that the teacher should keep the student curiosity alive during instruction, argued that the student's curiosity would vanish in two ways; the former is the old and repetitive information, and the second is the information that the students cannot comprehend. Therefore, the student should be provided with new and comprehensible things. The teacher should instruct the topics based on the student's knowledge level. This is difficult but necessary. The teacher could not teach anything unless she or he forgets that she or he is older than the children and thinks like them.

Halide Edip required the teachers to emphasize the students' imagination and to take measures to strengthen it. Thus, the teacher should know the types and characteristics of students' imagination. Children do not know the difference between the imagination and the reality. Their exaggerations are not lies, the teacher should be aware of this fact.

\section{Kaynakça / References}

Ali Kemal, (1339). Açık mektup. Peyam-ı Sabah, No: 11073.

Acun, F. (2015). Arnavutköy Amerikan Kız Koleji mezunları ve meşhurları. Cumhuriyet Tarihi Araştırmaları Dergisi, 22, 417-442.

Adıvar, H, E. (2005). Mor salkımlı ev. İstanbul: Özgür Yayınları.

Akyüz, Y. (1999). Osmanlı döneminde kızların eğitimi ve öğretmen Faika Ünlüer'in yetişmesi ve meslek hayatı. Milli Eğitim, 143, 12-32.

Altın, H. (2010) II. Meşrutiyet dönemi maarif nazırlarından Emrullah Efendi ve öğretmen yetiştirme tarihimize katkıları. Fırat Üniversitesi İlahiyat Fakültesi Dergisi, 15(2), 151-165. 
Altın, H. (2017). Osmanlı eğitim tarihinde dârülmuallimât:Açllışı ve gelişim süreci. Akademik MATBUAT, 1(1), 20-37.

Aliş, Ş. (2001) Tanzimat'tan Cumhuriyet'e edebiyatımızda öğretmen tipleri, Osmanlı dünyasında bilim ve eğitim, milletler arası kongresi tebliğleri. İslam Tarih, Sanat ve Kültür Araştırma Merkezi IRCICA, 12-15 Nisan 1999, İstanbul, 447-461.

Altay, D. (2010). Halide Edip Adivar. Ankara: Alter Yayınları.

Aydın H. (2015). Meşrutiyetten Cumhuriyete Türkiye'de kadın. Curr Res Soc Sci, 1(3), 84-96.

Başcl, V. (1999). Kadının statüsü üzerine bir inceleme, Atatürk Üniversitesi İlahiyat Fakültesi Dergisi, 14, 67- 78.

Bilge Y. (2012). Halide Edip'in Yedigün Dergisi'ndeki yazılarında kadına bakışı. International Journal of Social Science, 5(4), 43-61.

Bilkan A, F. (2005). Halide Edib Adıvar'ın "İnside İndia" adlı eseri ve Hindistan ziyareti. Bilig, 33, 119-136.

BOA, Dosya No: 65, Gömlek NO: 46.

Çalışlar, İ. (2011). Biyografisine sığmayan kadın Halide Edip. İstanbul: Everest Yayınları.

Cemal Paşa. (2012). Hatırât. (Haz. A. Z. İzgöer). İstanbul: DBY Yayınları.

Cemil Ö. (1988). Dünden Bugüne Türkiye'de Öğretmen yetiştiren kurumlar. İstanbul: Marmara Üniversitesi Atatürk Eğitim Fakültesi Yayınları.

Çopur, Y. (2010). Halide Edip Adıvar'ın Akşam Gazetesinde çıkan yazıları. Yayınlanmamış Yüksek Lisans Tezi, İstanbul: Marmara Üniversitesi Türkiyat Araştırmaları Enstitüsü.

Dolu, E. (1968), Pakistan'ın hayran olduğu Türk yazar. Hayat Tarih Mecmuası, $4(10), 64-66$.

Durakbaşa, A. (2017). Halide Edip Türk modernleşmesi ve feminizm. İstanbul: İletişim Yayınları.

Enginün, İ. (1978). Halide Edib Adıvar'ın eserlerinde Doğu ve Batı meselesi. İstanbul: İ. Ü. Edebiyat Fak. Yayınları.

Enginün, İ. (1988). Halide Edip Adıvar. TDVIA, 1, 376-377.

Erdal, K. (2008). Halide Edip Adıvar ve üniversite meselesi. Uludă̆ Ü. FenEdebiyat Fakültesi Sosyal Bilimler Dergisi, 9(15), 409 - 428.

Erdal, K. (2008). Halide Edib Adıvar'ın bakış açısıyla kadının çalışma hayatı. Gaziantep Üniversitesi Sosyal Bilimler Dergisi, 7(1), 109-123.

Erdal, K. (2008). Halide Edip Adıvar ve eğitim. İstanbul: Ezgi Kitapevi. 
Erdal K. (2005). Halide Edip Adıvar ve Halide Nusret Zorlutuna'nin eserlerinde öğretmen ve eğitim. Yayınlanmamış Doktora Tezi, Uludağ Üniversitesi Sosyal Bilimler Enstitüsü, Bursa

Ergün, M. (1996). II. Meşrutiyet devrinde eğitim hareketleri. Ankara: Ocak Yayınları.

Gaye, İ, H. (2015). Halide Edip Adıvar'ın hikâyelerinde kadınlar. Yayınlanmamış Yüksek Lisans Tezi, İhsan Doğramacı Bilkent Üniversitesi Ekonomi ve Sosyal Bilimler Enstitüsü, Ankara.

Gönenç, A, Y. (2004) Anadolu Ajansı'nın Türk basın tarihindeki yeri ve önemi. İletişim Fakültesi Dergisi, 19, 83-92.

Gözütok, T. (2010). Yeni Turan'da millî kimlik sorunu. Turkish Studies, 5(2), 410-448.

Halide Edip. (1327). Talim ve Terbiye. İstanbul: Tanin Matbaas1.

Halide Edip. (1335). Darülfununda kadın. Büyük Местиa, 6, 89.

Halide Edip. (1918). Evimize bakalım: Türkçülüğün faaliyet sahası. Vakit, $252,1$.

Halide Edip. (1924). Gökalp Ziya. Vakit, 2454, 4.

Halide Salih. (1324). Beşiği sallayan el dünyaya hükmeder. Tanin, 6, 2-3.

Halide Salih. (1324) Maarif Nezareti Daire-i Aliyesine, dârülmuallimât. Tanin, NO: 56.

Halide Salih. (1324). Mehasin okuyan kardeşlerime. Mehasin, 6, 418-421.

Kabaklı A. (1997). Türk edebiyatı. c.3. İstanbul: TEV Yayınları.

Kaplan M. (1992). Türk edebiyatı üzerinde araştırmalar I. İstanbul: Dergâh Yayınları.

Karabulut, R. (2017). Halide Edib Adıvar'ın romanlarında sosyal bir mesele olarak din/ İslam. Karadeniz, 36, 176-201.

Kazan F. (1995). Halide Edib ve Amerika. İstanbul: Bağlam Yayınları.

Koçak, A. (2017) Amerika' dan Boğaziçi'ne uzanan bir eğitimci Mary Mills Patrick'in Amerika'da kadınlara mahsus yüksek tahsil risalesi. Dil ve Edebiyat Araştırmaları, 16, 67-81.

Kurnaz, Ş. (1991). Balkan harbinde kadınlarımızın konferansları. Aile ve Toplum, 1(1), 15-23.

Küçükgörmen, G, K. (2010). Halide Edip Adıvar'ın romanlarında kadın ve kadın eğitimi. Yayınlanmamış Yüksek Lisans Tezi, Dokuz Eylül Üniversitesi Eğitim Bilimleri Enstitüsü, İzmir. 
Mutlu, G. (2016). Halide Edip Adıvar'ın "Mor Salkımlı Ev" ve "Sinekli Bakkal" adlı eserlerinin biçim ve içerik özellikleri ile değerler eğitimi açısından incelenmesi. Akra Uluslararası Kültür Sanat Edebiyat ve Ĕ̆itim Bilimleri Dergisi,12(5), 129-162.

Müezzinoğlu, E. (2017). İzmir milletvekili Halide Edip Adıvar'ın TBMM'deki faaliyetleri (1950-1954). Uluslararası Sosyal Araştırmalar Dergisi, 10(54), 331-339.

Ozansoy, M. F. (1964). Halide Edip Adıvar. Hisar, Şubat, 3-22.

Önertoy, O. (2011). Halide Edip Adıvar'ın romanlarında toplumsal eleştiri. Ankara Üniversitesi Dil ve Tarih-Coğrafya Fakültesi Türkoloji Dergisi, 18(1), 37-46.

Özkiraz, A, Arslanel, N. (2010). İkinci Meşrutiyet döneminde kadın olmak. Sosyal ve Beşeri Bilimler Dergisi, 3(1), 1-10.

Sağlam, H. (2015). Halide Edib Adıvar'ın Türk modernleşmesine katkısı. Yayınlanmamış Yüksek Lisans Tezi, Karadeniz Teknik Üniversitesi Sosyal Bilimler Enstitüsü, Trabzon.

Şahin, C ve Şahin, M. (2013). Osmanlı son dönemi ile milli mücadele yıllarında Türk kadınının sosyal, siyasî ve askerî faaliyetleri. NEÜ Sosyal Bilimler Enstitüsü Dergisi, 2, 53-72.

Şahin, N, A. (2012). Halide Edip Adıvar'ın romanlarında eğitim evreninin kronolojik açıdan incelenmesi. Yayınlanmamış Yüksek Lisans Tezi, Karadeniz Teknik Üniversitesi Eğitim Bilimleri Enstitüsü Trabzon.

Şahin, V. (2008). Kurmaca tekniği bakımından Halide Edip Adıvar'ın "Handan" romanı. Fırat Üniversitesi Sosyal Bilimler Dergisi, 18(2), 99-126.

Şahin, V. (2010). Halide Edip Adıvar'ın romanlarında yapı ve izlek. Yayınlanmamış Doktora Tezi, Fırat Üniversitesi, Sosyal Bilimler Enstitüsü, Elazı̆̆.

Şanal, M. (2004). Osmanlı İmparatorluğu'nda kız öğretmen okulunda görev yapan kadın idareci ve öğretmenler ile okutulan dersler. Belleten, 68(253), 649-670.

Şanal, M, Güçlü, M. (2005). Yenileşme dönemi eğitimcilerinin öğretmenlik mesleğine bakışları. Sosyal Bilimler Enstitüsü Dergisi, 18(1),137-154.

Şennur Ş. (2013). Kadın ve siyaset. Düşünce Dünyasında Türkiz Siyaset ve Kültür Dergisi, 4(20), 7-31.

Sönmez Ü, Ş. (2014), Halide Edip'in meşrutiyet romanına izleksel katkısı: kadın meselesi. 1. Uluslararası Türk Kültürü Araştırmaları Sempozyumu, Nevşehir, 216-225. 
Tanar, M. (2013). Kültür medeniyet ikilemi üzerinden Halide Edip'in düşüncesinde muhafazakârlık. Muhafazakâr Düşünce, 10(38), 161-180.

Taşer S. (2012). Halide Edip Adıvar'ın öğretmenlikten istifası. Selçuk Üniversitesi Türkiyat Araştırmaları Dergisi, 31, 149-159.

Taşkıran, T. (1973), Cumhuriyetin 50. yılında Türk kadın hakları. Ankara: Başbakanlık Kültür Müsteşarlığ 1 Yay.

Tuna, S. (1997). Halide Edip'in romanlarındaki kadınlar ve sorunları. Yayınlanmamış Yüksek Lisans Tezi, Selçuk Üniversitesi Sosyal Bilimler Enstitüsü, Konya.

Yılmaz, E. (2007). Türk Edebiyatında kadın öğretmen tiplemeleri. SAÜ Eğitim Fakültesi Dergisi, 14, 240-251.

Yılmaz, A. (2013). Halide Edip'te kadın hakları. Ankara Üniversitesi Dil ve Tarih-Coğrafya Fakültesi Türkoloji Dergisi, 20(1), 119-134.

Yavaş, G. (2017). Yeni Hayat'ın yeni öğretmen tipi: kaba softalıktan idealist öğretmenliğe Ali Şahin Efendi. Dil ve Edebiyat Araştırmaları, 15, 106107.

\section{Kaynakça Bilgisi / Citation Information}

Altın, H. (2019). Halide Edip'te eğitim fikri ve onun Talim ve Terbiye isimli eseri. OPUS-Uluslararası Toplum Araştırmaları Dergisi, 14(20), 1861-1895. DOI: 10.26466/opus.595764 